\title{
PENGARUH METODE PEMBELAJARAN PROBLEM SOLVING TERHADAP KEMAMPUAN BERPIKIR KRITIS MATEMATIKA
}

\author{
Noni Rahmawanty
}

SDS Borobudur.

\begin{tabular}{l} 
INFO ARTICLES \\
\hline Article History: \\
Received: 3-03-2017 \\
Revised: 10-03-2017 \\
Approved: 17-03-2017 \\
Publish Online: 18-04-2017 \\
\hline
\end{tabular}

Key Words:

Problem Solving Learning Method, Critical Thinking Ability

\section{(c) (1) (2)} under a Creative Commons AttributionShareAlike 4.0 International License.

\begin{abstract}
The research is aimed to determine and answer the problems about The impacts of problem solving learning method on mathematics critical thinking ability. The method is used in this research is experiment method with quantitative, and the analysis used $t$ test. The sample is the students grade $\mathrm{x}$ about 30 students is taken from each class by proportional random sampling. Based on normality test through liliefors test both of class in normal distribution and homogeneity test used $\mathrm{f}$ test and both of class is homogen. The result of hypothesis test show that $\mathrm{t}$ test (5.093) $>\mathrm{t}$ table (2.002), it means that problem solving method in SMK Islam Wijaya is more influence on mathematics critical thinking ability than problem solving based on learning method.
\end{abstract}

\begin{abstract}
Abstrak: Penelitian ini bertujuan untuk mengetahui dan menjawab permasalahan tentang pengaruh metode pembelajaran problem solving terhadap kemampuan berpikir kritis matematika. Metode yang digunakan peneliti adalah metode penelitian eksperimen dengan kuantitatif, dan analisisnya adalah uji t, sampelnya adalah peserta didik kelas X sebanyak 30 peserta didik dari masingmasing kelas dengan teknik samplingnya adalah Proporsional random sampling. Dari hasil perhitungan uji normalitas dengan menggunakan uji liliefors dimana kedua kelas berdistribusi normal, dan uji homogenitas dengan menggunakan uji $\mathrm{F}$ kedua kelas homogennya. Hasil uji hipotesis menunjukan bahwa nilai $t_{\text {hitung }}(5,093)>t_{\text {tabel }}(2,002)$ yang berarti penggunaan metode pembelajaran problem solving di SMK Islam Wijaya Kusuma, Lenteng Agung, Jakarta Selatan lebih berpengaruh terhadap kemampuan berpikir kritis matematika dibandingkan dengan penggunaan metode pembelajaran problem based learning.
\end{abstract}

Correspondence Address: , Jln. Cilandak KKO Jakarta Selatan, Indonesia; email : nonirahmaw@ gmail.com.

How to Cite (APA 6 ${ }^{\text {th }}$ Style): Rahmawanty, N. (2017). Pengaruh Metode Pembelajaran Problem Solving Terhadap Kemampuan Berpikir Kritis Matematika. JKPM (Jurnal Kajian Pendidikan Matematika), 02 (02), 201-210. DOI: 10.1007/XXXXXX-XX-0000-00

Copyright: Rahmawanty, N. (2017)

Competing Interests Disclosures: The authors declare that they have no significant competing financial, professional or personal interests that might have influenced the performance or presentation of the work described in this manuscript. 


\section{PENDAHULUAN}

Pendidikan merupakan hal terpenting yang dibutuhkan oleh setiap insan sebagai proses berpikirnya seseorang serta sebagai salah satu modal agar dapat meraih kesuksesan dalam kehidupannya. Melalui pendidikan, seseorang dapat dipandang terhormat, memiliki karir yang baik serta dapat bertingkah sesuai norma-norma yang berlaku. Mengingat peran pendidikan tersebut maka sudah sepantasnya menjadi perhatian pemerintah dalam rangka meningkatkan sumber daya masyarakat Indonesia yang berkualitas. Kualitas sumber daya manusia yang baik memiliki daya saing yang tinggi, sehingga mampu mengikuti kemajuan teknologi di era globalisasi kini. Pembangunan suatu bangsa dilakukan melalui peningkatan kualitas pendidikan. Upaya yang dilakukan oleh pemerintah Indonesia dalam meningkatkan kualitas pendidikan belum menampakkan hasil yang memuaskan. Permasalahan yang ada dalam dunia pendidikan bertambah dari tahun ke tahun, salah satu permasalahan utama yang dihadapi bangsa ini adalah rendahnya mutu pendidikan formal pada setiap jenjang pendidikan. Usaha telah dilakukan untuk meningkatkan mutu pendidikan nasional, antara lain melalui berbagai pelatihan dan peningkatan kompetensi guru, pengadaan buku dan alat pelajaran, perbaikan sarana dan prasarana pendidikan dan peningkatan mutu manajemen sekolah. Namun berbagai indikator mutu pendidikan belum menunjukan peningkatan yang berarti.

Banyak yang mempertanyakan apa yang salah dalam penyelenggaraan pendidikan kita. Ada banyak faktor yang menyebabkan mutu pendidikan tidak mengalami peningkatan yang bermakna, salah satunya adalah masalah lemahnya proses pembelajaran. Pada proses pembelajaran di sekolah, peserta didik harus menguasai semua mata pelajaran salah satunya adalah matematika. Peranan matematika diantaranya untuk meningkatkan daya nalar peserta didik dan dapat meningkatkan kemampuan berpikir logis, kritis, analitis, sistematis dan kreatif. Matematika juga menuntut peserta didik untuk fokus memutuskan apa yang seharusnya dipercaya atau dilakukan dengan mode berpikir mengenai hal atau masalah apa saja. Tetapi dalam mempelajari matematika yang menjadi masalah bagi peserta didik, matematika dianggap sulit dan tidak mudah untuk dipelajari dan peserta didik menganggap matematika pelajaran yang membosankan. Pembelajaran matematika yang dominan mengandalkan kemampuan daya pikir, perlu membina kemampuan berpikir siswa (khususnya berpikir kritis) agar mampu mengatasi permasalahan pembelajaran matematika yang materinya cenderung bersifat abstrak.

Hasil kajian dari Programme For Internasional Student Assessment (PISA), yaitu suatu studi internasional tentang prestasi literasi membaca, matematika, sains siswa sekolah berusia 15 tahun menempatkan Indonesia di urutan ke-64 dari 65 negara. Pada tahun 2012, Indonesia hanya mampu mengumpulkan 375 point dari skor rata-rata internasional 500 point untuk matematika. Menanggapi hasil PISA 2012, Guru Besar Matematika Institut Teknologi Bandung Iwan Pranoto (OECD, 2013) menilai, dari soal-soal yang diajukan dalam tes, bisa diketahui persentase murid Indonesia yang berhasil menjawab dengan benar. Selain itu, dapat diketahui kecakapan berpikir seperti apa yang dimiliki anak-anak Indonesia dan kelemahannya. Sebaiknya tidak melihat ranking Indonesia karena memang sudah diketahui hasilnya akan lemah, lebih baik melakukan analisis setiap pertanyaan yang diajukan. Sejak tahun 2000 performa murid Indonesia buruk di PISA, jika dilihat dari soal-soal yang diajukan, kecakapan matematika yang diharapkan dunia melalui tes PISA itu berbeda dengan yang diajarkan di sekolah dan yang diujikan dalam ujian nasional. Hal ini tidak berarti matematika di Indonesia lebih mudah daripada di negara lain yang meraih ranking lebih tinggi dalam PISA, sekolah di Indonesia hingga saat ini belum memaksimalkan tujuan pembelajaran.

Tujuan pembelajaran khususnya matematika dapat dilakukan dengan mengembangkan pola pikir rasional, kritis dan kreatif serta membentuk sikap konstruktif. Untuk mengembangkan pola pikir tersebut 
dapat dilakukan dengan menggunakan kemampuan berpikir kritis matematika, hanya saja kebiasaan berpikir kritis ini belum ditradisikan di sekolah-sekolah. Seperti yang diungkapkan kritikus Jacqueline dan Brooks (Santrock, 2007:19), sedikit sekolah yang mengajarkan peserta didiknya berpikir kritis. Sekolah justru mendorong peserta didik memberi jawaban yang benar daripada mendorong mereka memunculkan ide-ide baru atau memikirkan ulang kesimpulan-kesimpulan yang sudah ada. Hal ini sesuai dengan hasil wawancara pada peserta didik di SMK Islam Wijaya Kusuma, mereka mengungkapkan banyak dari teman-teman mereka untuk mata pelajaran matematika yang mendapatkan nilai di bawah standar KKM yang telah ditentukan oleh sekolah, kalaupun ada yang mendapatkan nilai diatas KKM setiap kelas hanya didapat satu atau dua orang saja, mereka mengakui jika proses pembelajaran matematika yang dilakukan di sekolah lebih sering menggunakan metode konvensional ceramah yang terkadang membuat mereka jenuh bahkan banyak dari teman-teman mereka yang kadang asik sendiri dan tidak memperhatikan guru sedang menerangkan saat pelajaran berlangsung.

Kemampuan berpikir kritis matematika sangat penting dalam kehidupan sehari-hari, karena dengan adanya pola pikir manusia akan menemukan apa yang akan dianalisanya. Seperti halnya kemampuan untuk membuat keputusan dan menyelesaikan masalah yang ada dalam kehidupan sehari-hari. Dengan demikian, guru harus menemukan metode pembelajaran matematika yang tepat agar terciptanya kemampuan berpikir kritis peserta didik dalam menyelesaikan masalah pembelajaran matematika. Agar proses pembelajaran matematika terorganisir dengan baik dan untuk mengatasi berbagai permasalahan matematika, pada ranah ini peranan guru sangat penting dalam merancang metode pembelajaran.

Pada umumnya sedikit sekolah yang menggunakan metode pembelajaran yang mengutamakan kemampuan berpikirnya, sehingga terjadi proses pembelajaran antara guru dan peserta didik secara simbolis atau abstrak. Peserta didik hanya menghafalkan puluhan rumus matematika kemudian mengerjakan soal secara prosedural tanpa adanya penalaran yang kuat, sedangkan cara belajar matematika dengan cara menghafal akan cepat lupa dan tidak dapat diaplikasikan dalam kehidupan sehari-hari. Untuk itu, metode pembelajaran Problem Solving yakni salah satu metode pembelajaran yang menggunakan kemampuan untuk memecahkan masalah yang dimiliki seseorang diharapkan mampu mengatasi permasalahan kemampuan berpikir kritis matematika. Kemampuan tersebut dapat ditunjukkan melalui beberapa indikator, misalnya mampu mengidentifikasi masalah, memiliki rasa ingin tahu, bekerja secara teliti dan mampu mengevaluasi keputusan. Hal inilah yang melatih siswa agar dapat berkemampuan berpikir tingkat tinggi guna mendukung reformasi proses pembelajaran yang ada pada kurikulum 2013.

Berpikir kritis adalah suatu cara yang dilakukan seseorang secara sadar atas pengetahuan yang dimilikinya untuk menemukan apa yang di analisanya. Berpikir kritis juga sebagai proses kegiatan mengambil keputusan dalam memecahkan masalah secara terarah dan terorganisasi dengan baik sehingga menghasilkan pemecahan masalah dengan tepat. Hal ini berarti berpikir kritis merupakan pemikiran yang menggunakan pertimbangan yang aktif, terus menerus dan cermat terhadap informasi dan keyakinan dengan mempertimbangkan bukti-bukti yang mendukung untuk mempercayai atau melakukan sesuatu.

Peserta didik yang memiliki kemampuan berpikir kritis akan selalu bertanya pada diri sendiri dalam setiap menghadapi segala persoalan untuk menentukan yang terbaik bagi dirinya. Banyak para ahli yang memberikan gambaran tentang berpikir kritis, salah satunya menurut Wade (Nurhayati, 2011:68) bahwa berpikir kritis dapat diidentifikasikan berdasarkan karakteristik meliputi: (1) kegiatan merumuskan pertanyaan, (2) membatasi permasalahan, (3) menguji data-data, (4) menganalisis berbagai pendapat, (5) menghindari pertimbangan yang sangat emosional, (6) menghindari penyederhanaan berlebihan, (7) mempertimbangkan berbagai interpretasi, (8) menoleransi ambiguitas. Kemampuan berpikir kritis 
matematika merupakan kemampuan berpikir kritis pada bidang ilmu matematika. Hal ini sejalan dengan pendapat Noer (2009:473) kemampuan berpikir kritis matematika khususnya berpikir matematis tingkat tinggi sangat diperlukan siswa, terkait dengan kebutuhan siswa untuk memecahkan masalah yang dihadapinya dalam kehidupan sehari-hari. Oleh sebab itu, kemampuan berpikir kritis matematika terutama yang menyangkut doing math (aktivitas matematika) perlu mendapatkan perhatian khusus dalam proses pembelajaran matematika.

Kemampuan berpikir kritis matematika bukan hanya untuk mencari jawaban semata, tetapi yang paling utama adalah untuk mempertanyakan informasi yang diberikan. Pada kemampuan berpikir kritis matematika ini seseorang dituntun agar berpikir dengan mandiri dan lebih terarah, sehingga mampu menyelesaikan permasalahan matematika yang dihadapi. Permasalahan matematika memang sangat dibutuhkan kemampuan berpikir yang dapat mengarahkan pemikiran seseorang untuk berpikir secara kritis, karena dalam menyelesaikan soal matematika tidak hanya menjawab pertanyaan sesuai dengan contoh saja akan tetapi soal yang diberikan terdapat tingkatannya seperti soal yang mudah, sedang lalu sukar. Untuk itu sangat dibutuhkan kemampuan berpikir secara kritis dalam menyelesaikan pembelajaran matematika.

Dalam kegiatan belajar mengajar, metode diperlukan oleh guru dan penggunaannya bervariasi sesuai dengan tujuan yang ingin dicapai setelah pengajaran berakhir. Tujuan pembelajaran merupakan syarat mutlak bagi guru dalam memilih metode yang akan digunakan dalam menyajikan materi pengajaran. Hal ini sejalan dengan pendapat Sanjaya (2011:294) bahwa metode adalah upaya mengimplementasikan rencana yang sudah disusun dalam kegiatan nyata agar tujuan yang telah disusun tercapai secara optimal. Melalui metode, kegiatan pembelajaran akan terarah dan tersusun sesuai rencana yang diharapkan. Bertolak dari uraian di atas, penulis melaksanakan penelitian mengenai pengaruh metode pembelajaran problem solving terhadap kemampuan berpikir kritis matematika, eksperimen pada peserta didik kelas X di SMK Islam Wijaya Kusuma, Lenteng Agung, Jakarta Selatan.

\section{METODE}

Untuk memecahkan suatu masalah, penggunaan suatu metode sangatlah penting. Sesuai dengan masalah yang hendak dipecahkan dan tujuan yang hendak dicapai serta hipotesis yang diajukan, maka penelitian ini menggunakan metode quasy experiment, yaitu dengan adanya perlakuan kepada objek penelitian. Sesuai dengan judul dan masalah yang ada, pelaksanaan penelitian ini menggunakan desain penelitian posttest only control design artinya terdapat dua kelas yang masing-masing dipilih secara acak dengan tes hanya di akhir perlakuan.

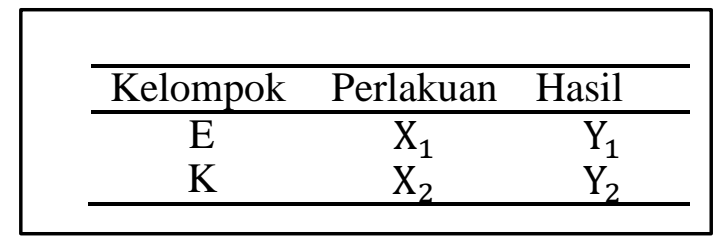

Gambar 1. Desain Penelitian 
Keterangan:

E : Kelompok kelas eksperimen

K : Kelompok kelas kontrol

$\mathrm{X}_{1}$ : Perlakuan untuk kelas eksperimen dengan menggunakan metode problem solving

$\mathrm{X}_{2}$ : Perlakuan untuk kelas kontrol dengan menggunakan metode problem based learning

$\mathrm{Y}_{1}$ : Skor hasil posttest kemampuan berpikir kritis matematika pada kelas eksperimen

$\mathrm{Y}_{2}$ : Skor hasil posttest kemampuan berpikir kritis matematika pada kelas kontrol

Penelitian ini dilaksanakan di SMK Islam Wijaya Kusuma yang beralamat di Jln. Raya Depok No.16, Lenteng Agung, Jagakarsa, Jakarta Selatan 12610. Penelitian dilakukan pada bulan April s. d. Mei tahun ajaran 2016/2017. Populasi target dalam penelitian ini adalah semua peserta didik di SMK Islam Wijaya Kusuma, Lenteng Agung, Jagakarsa, Jakarta Selatan. Populasi terjangkau pada penelitian ini adalah hanya peserta didik kelas X di SMK Islam Wijaya Kusuma sebanyak 243 peserta didik tahun ajaran 2016/2017. Sampel pada penelitian ini diambil dua kelas yaitu kelas eksperimen dan kelas kontrol. Kelas eksperimen dalam pembelajaran menggunakan metode problem solving dan kelas kontrol dalam pembelajaran menggunakan metode problem based learning. Dari masing-masing kelas yang dijadikan anggota sampel diambil 30 peserta didik, sehingga total sampel 60 peserta didik.

Teknik penentuan sampel yang digunakan adalah simple random sampling (sampel acak sederhana). Pengambilan sampel dalam penelitian ini dilaksanakan dengan cara mengundi, adapun langkah-langkahnya adalah sebagai berikut: (a) Membuat daftar kelas X yang terdiri dari jurusan AP (Administrasi Perkantoran) dan AK (Akuntansi) pada kertas kecil dan memasukannya ke dalam kaleng pengocok; (b) Setelah didapat 2 kelas kemudian membuat daftar nomor urut dari absen siswa kelas AP-2 dan AP-3 pada kertas kecil dan memasukannya ke dalam kaleng pengocok; dan (3) Mengocok baik-baik kaleng tersebut dan mengambil satu persatu untuk menentukan 30 peserta didik yang akan dijadikan sampel masing-masing dari kelas AP2 dan AP-3 sehingga total 60 peserta didik.

Data tentang metode pembelajaran problem solving berupa data kualitatif yang diperoleh dari jurnal, buku dan referensi kepustakaan yang relevan. Data tentang kemampuan berpikir kritis matematika diperoleh dari peserta didik yang menjadi sampel penelitian. Untuk memperoleh data penelitian tentang kemampuan berpikir kritis matematika melalui tes tulis berupa soal essay sebanyak 15 butir soal. Soal disusun berdasarkan kisi-kisi yang secara keseluruhan meliputi kompetensi dasar: (a) Menentukan jarak antara dua titik dan jarak titik ke garis; (b) Menentukan jarak antara titik dengan bidang dan jarak antara dua garis bersilangan dalam ruang dimensi tiga; (c) Menentukan jarak antara dua garis sejajar dalam ruang dimensi tiga; (d) Menentukan jarak antara garis dan bidang dalam ruang dimensi; dan (e) Menentukan jarak antara dua bidang yang sejajar dalam ruang dimensi.

Kemampuan berpikir kritis matematika merupakan kemampuan berpikir secara mendalam terhadap suatu permasalahan dengan melibatkan data yang ada untuk menghasilkan suatu kesimpulan yang logis dalam mempelajari matematika. Kemampuan berpikir kritis matematika adalah skor yang diperoleh peserta didik untuk menguji kemampuan berpikir kritis matematika yang diukur dengan 15 butir soal essay pada materi dimensi III dengan indikator kemampuan berpikir kritis (Ennis, 2000:26) diantaranya Elementary clarification (memberikan penjelasan sederhana), meliputi: memfokuskan pertanyaan, menganalisis 
argumen, bertanya dan menjawab tentang suatu penjelasan atau tantangan; Basic support (membangun keterampilan dasar), meliputi: mempertimbangkan kredibilitas sumber, mengobservasi dan mempertimbangkan hasil observasi; Inference (menyimpulkan), meliputi: membuat deduksi dan mempertimbangkan hasil deduksi, membuat induksi dan mempertimbangkan hasil keputusan; Advance clarification (memberikan penjelasan lebih lanjut), meliputi: mendefinisikan istilah dan mempertimbangkan definisi, mengidentifikasi asumsi; Strategy and tactics (Strategi dan taktik), meliputi: memutuskan suatu tindakan, berinteraksi dengan orang lain.

Sebelum digunakan untuk mengumpulan data penelitian, instrumen tes kemampuan berpikir kritis matematika diujicoba terlebih dahulu ke peserta didik kelas X yang tidak termasuk dalam sampel penelitian. Karakteristik instrumen: ranah kognitif C2, C3, dan C4. Semua butir soal dinyatakan valid dengan skor korelasi diantara 0,374 s.d. 0,541; hasil daya beda berada pada rentang 0,367 s.d. 0,733 yang masuk kategori cukup baik, baik, dan sangat baik; tingkat kesukaran semua butir soal masuk kategori sedang; dan skor reliabilitas 0,630 .

\section{HASIL PENELITIAN}

Sebelum dilakukan pengujian hipotesis, terlebih dahulu harus dilakukan uji persyaratan analisis data, yang meliputi uji normalitas dan uji homogenitas.

\section{Pengujian Persyaratan Analisis}

\section{a. Uji Normalitas}

Uji normalitas diberikan kepada kedua kelompok kelas yang diberikan perlakuan berbeda dan diharapkan data yang diperoleh dari hasil penelitian berdistribusi normal, untuk menguji kenormalan hasil penelitian digunakan uji Liliefors. Adapun simpulan hasil uji normalitas, dapat dilihat dari tabel 1. Berdasarkan tabel 1, dapat terlihat bahwa nilai Liliefors untuk kelompok eksperimen dan untuk kelompok kontrol lebih besar $\alpha=(0,05)$, ini berarti distribusi nilai pada setiap kelas berdistribusi normal.

Tabel 1. Simpulan Hasil Uji Normalitas Data

\begin{tabular}{lccl}
\hline Kelompok Data & $\boldsymbol{L}_{\mathbf{0}}$ & $\boldsymbol{L}_{\boldsymbol{t}}$ & Simpulan \\
\hline Eksperimen & 0,146 & 0,161 & Normal \\
Kontrol & 0,154 & 0,161 & Normal \\
\hline
\end{tabular}

\section{b. Uji Homogenitas}

Selanjutnya dilakukan uji homogenitas. Uji homogenitas dimaksudkan untuk menguji apakah data dari masing-masing sampel mempunyai varians yang sama atau tidak. Adapun simpulan hasil uji homogenitas, dapat dilihat dari tabel 2. Berdasarkan tabel 2, dapat terlihat bahwa nilai hasil $\mathrm{F}_{\text {hitung }}=1,648$ dan $\mathrm{F}_{\text {tabel }}=$ 1,882 atau $F_{\text {hitung }}(1,648)<\mathrm{F}_{\text {tabel }}(1,882)$ sehingga $\mathrm{H}_{0}$ diterima dan dapat disimpulkan bahwa kedua kelompok memiliki varians yang sama atau homogen.

Tabel 2. Simpulan Hasil Uji Homogenitas Varians

\begin{tabular}{llllll}
\hline $\begin{array}{l}\text { Kelompok } \\
\text { Data }\end{array}$ & $\begin{array}{l}\text { Jumlah } \\
\text { Sampel }\end{array}$ & $\begin{array}{l}\text { Varians } \\
\left(\boldsymbol{S}^{\mathbf{2}}\right)\end{array}$ & $\boldsymbol{F}_{\text {hitung }}$ & $\boldsymbol{F}_{\text {tabel }}$ & Simpulan \\
\hline Eksperimen & 30 & 129,96 & 1,648 & 1,882 & Terima $H_{0}$ \\
Kontrol & 30 & 78,85 & & & \\
\hline
\end{tabular}




\section{Pengujian Hipotesis}

Setelah melakukan beberapa uji persyaratan data di atas, didapat dua kelompok yang masing-masing memiliki data berdistribusi normal dan homogen. Dari hasil perhitungan tersebut didapat nilai rata-rata untuk kelompok eksperimen sebesar 81,1 dan nilai rata-rata untuk kelompok kontrol sebesar 67,67. Dengan kriteria pengambilan keputusan

Terima $H_{0}$ jika $t_{\text {hitung }}<t_{\text {tabel }}$

Tolak $H_{0}$ jika $t_{\text {hitung }}>t_{\text {tabel }}$

Dari hasil perhitungan diperoleh bahwa nilai $t_{\text {hitung }}=5,093>t_{\text {tabel }}=2,002$, maka $H_{0}$ ditolak. Artinya rata-rata kemampuan berpikir kritis matematika yang diberikan metode pembelajaran problem solving tidak sama dengan rata-rata kemampuan berpikir kritis matematika yang diajarkan dengan metode pembelajaran problem based learning.

\section{PEMBAHASAN}

Berdasarkan hasil penelitian, dapat diketahui bahwa penggunaan metode pembelajaran problem solving memiliki pengaruh terhadap kemampuan berpikir kritis matematika. Hal ini ditunjukan dengan hasil uji $\mathrm{t}$ diperoleh nilai $t_{\text {hitung }}(5,093)>t_{\text {tabel }}(2,002)$. Dari deskripsi data yang diperoleh bahwa nilai kemampuan berpikir kritis matematika kelas eksperimen dari 30 peserta didik nilai tertinggi 94 dan nilai terendah 60 memiliki rata-rata 81,1. Sedangkan nilai kemampuan berpikir kritis matematika kelas kontrol dari 30 peserta didik dengan nilai tertinggi 84 dan nilai terendah 55 memiliki rata-rata 67,67 sehingga dapat dikatakan bahwa nilai rata-rata kemampuan berpikir kritis matematika kelas eksperimen lebih tinggi daripada nilai rata-rata kemampuan berpikir kritis matematika kelas kontrol.

Hasil pengolahan analisis data menunjukkan bahwa penerapan metode pembelajaran problem solving terhadap kemampuan berpikir kritis matematika lebih baik daripada penerapan metode pembelajaran problem based learning. Hal ini juga dapat dilihat dari proses pembelajaran yang cenderung baik, karena peserta didik secara aktif mengikuti semua rangkaian kegiatan proses pembelajaran secara aktif dan antusias baik secara kelompok maupun individu. Dari penelitian ini diperoleh bahwa peserta didik awalnya menganggap pelajaran matematika menakutkan dengan banyaknya rumus-rumus dan perhitungan yang rumit sehingga membuat peserta didik ketika mendapatkan pelajaran matematika merasa bosan dan jenuh. Oleh karena itu, peneliti mencoba menerapkan pembelajaran yang dapat membiasakan peserta didik menyelesaikan soal-soal dengan menggunakan metode pembelajaran problem solving. Selain itu, dilihat dari proses pembelajaran yang menggunakan metode pembelajaran problem based learning pada saat diterapkan di SMK Islam Wijaya Kusuma cenderung kurang baik karena pada awal proses pembelajaran peserta didik dituntut untuk mandiri memecahkan masalah yang belum diajarkan sehingga peserta didik merasa kebingungan dan sulit untuk bekerjasama dengan teman sekelompoknya, peserta didik juga merasa tidak tertarik dan mencari tahu untuk menyelesaikan masalah yang dihadapi.

Secara umum kemampuan berpikir kritis matematika adalah penentuan secara hati-hati dan sengaja apakah menerima, menolak atau menunda keputusan tentang suatu klaim atau pernyataan. Ketika seorang peserta didik mempertimbangkan suatu pernyataan, hal itu menunjukkan bahwa peserta didik tersebut telah mempunyai sejumlah informasi yang relevan dengan pernyataan tersebut, secara umum dapat digambarkan cara mendapatkan informasi yang lebih banyak jika diperlukan. Keinginan dan kemampuan untuk memperoleh informasi yang menghasilkan suatu keputusan adalah bagian dari proses berpikir kritis. Hal ini 
diperkuat oleh pendapat Lestari (2014:40) bahwa kemampuan berpikir kritis matematika adalah kemampuan berpikir dalam menyelesaikan masalah matematika yang melibatkan pengetahuan matematika, penalaran matematika dan pembuktian matematika. Khususnya pada pelajaran matematika, dengan menggunakan kemampuan berpikir secara kritis dapat memudahkan menyelesaikan berbagai masalah matematika seperti yang telah diterangkan sebelumnya bahwa kemampuan berpikir kritis dapat memecahkan masalah matematika, sehingga dapat diperoleh hasil yang dibutuhkan. Kemampuan berpikir kritis matematika merupakan kemampuan secara esensial untuk kehidupan, pekerjaan, dan berfungsi efektif dalam semua aspek kehidupan lainnya. Kemampuan berpikir kritis juga sangat penting bagi peserta didik, karena dengan kemampuan ini peserta didik mampu bersikap rasional dan memilih alternatif pilihan yang terbaik bagi dirinya.

Hasil penelitian ini didukung oleh hasil penelitian dari Monalika (2011), secara terperinci dipaparkan hasil dari pengolahan data menunjukkan bahwa rata-rata kemampuan berpikir kritis matematika yang diajarkan menggunakan metode pembelajaran problem solving (kelas eksperimen) memiliki nilai rata-rata sebesar 110,81 dan kemampuan berpikir kritis matematika yang diajarkan menggunakan Open Ended (kelas kontrol) memiliki nilai rata-rata sebesar 109,91. Kesimpulan peneliti adalah "metode pembelajaran problem solving memberikan pengaruh yang signifikan terhadap kemampuan berpikir kritis matematika, dibandingkan dengan metode pembelajaran Open Ended". Dari penelitian tersebut menunjukan bahwa ada perbedaan antara peran aktif dan kemampuan berpikir kritis yang diajar menggunakan metode pembelajaran problem solving lebih tepat diterapkan daripada metode pembelajaran open ended. Penggunaan metode problem solving dalam pembelajaran matematika memiliki kontribusi yang besar daripada metode open ended. Maka penulis melakukan penelitian dengan metode pembelajaran problem solving sebagai kelas eksperimen dan metode pembelajaran problem based learning sebagai kelas kontrol diperoleh bahwa metode pembelajaran problem solving berpengaruh terhadap kemampuan berpikir kritis matematika.

Sejalan dengan Pranita (2014) yang mana simpulan peneliti adalah "metode pembelajaran problem solving memberikan pengaruh yang signifikan terhadap hasil belajar matematika, dibandingkan dengan metode pembelajaran inkuiri”. Salah satu metode yang dianggap tepat dalam pembelajaran matematika adalah metode pembelajaran problem solving. Metode pembelajaran problem solving adalah metode pembelajaran yang digunakan sebagai alternatif dalam pembelajaran matematika. Kondisi yang diharapkan dengan penerapan metode pembelajaran problem solving yaitu pembelajaran menjadi efektif dan efisien, peserta didik lebih antusias untuk dapat mengerjakan soal-soal matematika agar tujuan pembelajaran dapat tercapai. Soal matematika yang dihadapi peserta didik seringkali tidak segera dicari solusinya, untuk itu dibutuhkannya kemampuan berpikir kritis matematika agar dapat menemukan cara yang tepat untuk menyelesaikan masalah yang dihadapi. Hal ini memepertegas bahwasanya kelebihan metode pembelajaran Problem Based Learning menurut Sanjaya (2007:219), yaitu menantang kemampuan peserta didik serta memberi kepuasan untuk menemukan pengetahuan baru bagi peserta didik.

Metode pembelajaran Problem Based Learning merupakan metode pembelajaran yang digunakan untuk mengolah kemampuan peserta didik dalam menyelesaikan soal matematika dengan menganalisis soal dan mengaitkannya dengan masalah yang berhubungan dengan kehidupan sehari-hari. Hal ini sejalan dengan pendapat Purnamaningrum (2012:2) bahwa Problem Based Learning (PBL) merupakan pembelajaran yang dilakukan dengan menghadapkan siswa pada permasalahan yang nyata pada kehidupan sehari-hari, sehingga siswa dapat menyusun pengetahuannya sendiri dalam memecahkan masalah dan mengupayakan berbagai macam solusinya sehingga mendorong siswa untuk berpikir positif. Berpikir positif adalah cara untuk memecahkan suatu permasalahan dengan baik, dengan demikian siswa dapat menemukan solusi-solusi dalam suatu permasalahan pada kehidupan sehari-hari sehingga pengetahuan yang didapat akan menjadi pedoman dalam memecahkan masalah. 
Peneliti mencoba memberikan beberapa saran, diantaranya untuk pihak sekolah, seyogyanya pihak sekolah berupaya meningkatkan kompetensi tenaga pendidik dalam setiap pembelajaran matematika dengan pendekatan, metode, maupun teknik pembelajaran yang menarik perhatian dan minat peserta didik sehingga kemampuan berpikir kritis matematika yang ada pada diri peserta didik dapat berkembang, sehingga peserta didik mendapatkan hasil yang baik dalam pelajaran matematika.Tenaga pendidik hendaknya dengan tekun meningkatkan profesionalitasnya dengan meningkatkan kapasitasnya, serta tenaga pendidik terus berinovasi dalam pengembangan metode pembelajaran yang baik dan cocok digunakan dalam pelaksanaan proses belajar mengajar.

Peserta didik hendaknya menguasai materi-materi yang telah diajarkan sehingga memiliki bekal pengetahuan yang cukup, dengan terus mencari dan menambah wawasan ilmu pengetahuan. Teman-teman mahasiswa yang berminat untuk melakukan penelitian yang sama disarankan untuk melibatkan variabel lain atau objek penelitian yang lebih luas guna mengembangkan sistem pendidikan di Indonesia.

\section{SIMPULAN}

Berdasarkan hasil penelitian ini bahwa terdapat pengaruh metode pembelajaran problem solving terhadap kemampuan berpikir kritis matematika. Kemampuan berpikir kritis matematika yang menggunakan metode pembelajaran problem solving lebih baik digunakan daripada menggunakan metode pembelajaran problem based learning, hal ini dapat dilihat dari perhitungan uji $\boldsymbol{t}$ diperoleh nilai $\boldsymbol{t}_{\text {hitung }}$ $(5,093)>\boldsymbol{t}_{\text {tabel }}(2,002)$. Rata-rata kemampuan berpikir kritis matematika yang mengikuti metode pembelajaran problem solving lebih baik dibanding rata-rata kemampuan berpikir kritis matematika yang mengikuti metode pembelajaran problem based learning. Hal ini berarti penggunaan metode pembelajaran problem solving di SMK Islam Wijaya Kusuma, Lenteng Agung, Jakarta Selatan lebih mempengaruhi kemampuan berpikir kritis matematika dibanding dengan penggunaan metode problem based learning..

\section{DAFTAR RUJUKAN}

Ennis, R. W. (2000). Critical Thinking. New Jersey: Prentice-hall.

Lestari, K. E.(2014). Implementasi Brain-Based Learning untuk meningkatkan kemampuan koneksi dan kemampuan berpikir kritis serta motivasi belajar siswa SMP. Jurnal Pendidikan Unsika. Volume 2 (1): 40.

Monalika. (2011). Pengaruh Metode Problem Solving terhadap Kemampuan Berpikir Kritis Matematika. Skripsi: 2015 Penelitian tidak diterbitkan. Diakses pada 11 April 2017.

Noer, S. H. (2009). Peningkatan Kemampuan Berpikir Kritis Matematis Siswa SMP Melalui Pembelajaran Berbasis Masalah. Lampung: Jurnal Formatif (2):473-474.

Nurhayati, E. (2011). Psikologi Pendidikan Inovatif. Yogyakarta: Pustaka Pelajar.

OECD. (2013). http://www.oecd.org/publications/pisa-2012-results-volume-i-9789264266490-enhtm. Diakses pada April 2017. 
Pranita, M. (2014). Pengaruh Metode Pembelajaran Problem Solving terhadap Hasil Belajar Matematika. Skripsi: Penelitian tidak diterbitkan. Diakses pada 11 April 2017.

Purnamaningrum, A. (2012). Peningkatan Kemampuan Berpikir Kreatif melalui Problem Based Learning pada pembelajaran biologi siswa kelas X SMA Negeri 3 Surakarta tahun pelajaran 2011/2012. Jurnal Pendidikan Biologi, 4 (3):39-51.

Sanjaya. (2007). Strategi Pembelajaran Berorentasi Standar Proses Pendidikan. Jakarta: Kencana Prenada Media Group. . (2011). Kurikulum dan Pembelajaran. Jakarta: Prenada Media Group.

Santrock, J. W. (2007). Perkembangan Anak. Jakarta: Erlangga.

Yusuf, dkk. (2013). Pengembangan Soal-Soal Open Ended pada Pokok Bahasan Segitiga dan Segiempat di SMP. Jakarta: Jurnal Pendidikan Matematika (3):49-56. 